\title{
Haloperidol and Biperiden Plasma Levels in A Pregnant Atypical Psychotic Woman and A Neonate
}

\author{
- A Case Report - \\ MASAHIRO KUNIYOSHI AND KAZUTOYO INANAGA \\ Department of Neuropsychiatry, Kurume University School of Medicine, \\ Kurume, 830 Japan
}

Received for publication June 6, 1985

\begin{abstract}
Summary: A pregnant mother was given haloperidol and biperiden for atypical psychosis. Plasma concentrations of haloperidol and biperiden in the mother and the neonate were measured. Blood was collected at the time of delivery. Lactation was stopped with hexestrol, however milk was secreted from the 25 th day in the hospital in spite of the hexestrol injection. Haloperidol and biperiden concentrations of the breast milk were also measured. The findings indicate that injections of haloperidol and biperiden to the mother for a short period have no deleterious effects on neonatal development. There are few reports on the concentration of haloperidol in neonatal plasma at the time of delivery, and nothing on the concentration of biperiden in neonatal plasma.
\end{abstract}

Key words: Haloperidol - Biperiden - Plasma level — Level of breast milk Pregnancy

\section{Introduction}

Atypical psychosis is not a rare disease in psychiatric clinics. But reports on pregnancy and delivery in these patients are limited. Also, the literature on plasma concentrations of haloperidol (Serenace) and biperiden (Akineton), sampled at the time of delivery, is incomplete. Blood samples from a patient with this disease were collected and the concentrations of haloperidol and biperiden were measured. The neonatal umbilical plasma concentrations of the drugs at the time of delivery were also measured. The neonate was in very good condition and did not have any extrapyramidal dysfunctions. Lactation by the mother was stopped with drugs to avoid ingestion of the drugs by the neonate during breast feeding.

It was concluded that administration of haloperidol and biperiden for a short time is a comparatively safe method to control the pregnant psychiatric patient during the last 3 weeks of pregnancy. Biperiden may be a useful drug to prevent unexpected extrapyramidal dysfunction in the neonate.

\section{Case Report}

A 31-year-old pregnant woman entered our hospital with the complaint of "I want to sleep, and furthermore I want to die". She had been repeatedly hospitalized 7 times since she was 16 years-old, with the diagnosis of atypical psychosis.

Her husband was a 36 year-old schizophrenia, who was hospitalized 4 months before her admission. This was her second pregnancy. She had no problems during her first pregnancy because her husband's 
mother provided nursing help. But this time, she was afraid of continuing her pregnancy because she had no help to take care of her neonate. In fact, her husband's mother was ill and could not help her.

Her pregnancy was 36 weeks on admission. She desired to separate herself from her fetus and to sleep deeply. She became very irritable and aggressive. An induced delivery was planned for the 37 th week of pregnancy, because it was impossible to continue the pregnancy with her psychiatric condition. She was in a schizophrenic and depressed state. Associative disturbances, autism, affective incongruity, ambivalence, thought blocking, delusions of persecution, auditory hallucinations, stereotypy, mannerisms, catalepsy and suicidal attempts during depressive moods were observed. Haloperidol, $3 \mathrm{mg} /$ day, and biperiden, $3 \mathrm{mg} /$ day, were orally administered for her condition and the dosage was increased as needed. But her condition became worse, so the medication was changed to $5 \mathrm{mg}$ haloperidol and $5 \mathrm{mg}$ biperiden, intramuscularly twice a day.

On her 17 th day in the hospital, she delivered a $3260 \mathrm{~g}$ male baby. The apgar scores were 9 at one and five minutes. The neonate's reflexes were all normal and he did not show any extrapyramidal dys- functions. Maternal blood and neonatal umbilical blood were collected and the concentrations of haloperidol and biperiden were measured.

The mother's psychiatric conditions changed rapidly after delivery. Her psychotic state completely disappeared and she was normal by the $3 \mathrm{rd}$ day after delivery. Lactation was stopped with hexestrol to avoid ingestion of haloperidol and other drugs by the neonate. The neonate was given artificial milk instead of his mother's breast milk. The neonate did not have any difficulties and was discharged 6 days after birth. The mother was discharged after 31 days in the hospital, as she was normal.

The drug dosages and days of sampling are shown in Table 1. Blood samples from the mother and the neonate were collected at the time of delivery and one minute after birth, repectively. The mother was injected with $5 \mathrm{mg}$ haloperidol and $5 \mathrm{mg}$ biperiden, intramuscularly, 3.5 hours before delivery. A breast milk sample was collected 12 days after delivery.

The samples were frozen in vacutainer blood tubes. The concentrations of haloperidol and biperiden were determined by Dainippon Pharmaceutical Co. Ltd., Research Laboratory, Physical and Analytical Chemistry using gas chromatographic me-

TABLE 1

Drug dosages and sampling days

\begin{tabular}{|c|c|c|c|c|c|c|c|}
\hline inhospital day & 1 & $\cdots \cdots \cdots, 9,10$ & …… & 15 & 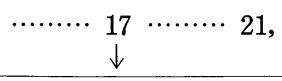 & 22 & 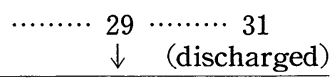 \\
\hline (p. o.) & & & & & $\begin{array}{c}\text { delivery day } \\
\text { (plasma sample) }\end{array}$ & & $\left(\begin{array}{l}\text { breast milk } \\
\text { sampling }\end{array}\right)$ \\
\hline $\begin{array}{l}\text { Haloperidol } \\
\text { (mg/day) }\end{array}$ & 3 & $\begin{array}{lll}\cdots \cdots \cdots & 3, & 6\end{array}$ & $\cdots \cdots \cdots$ & & & 6 & ....... \\
\hline $\begin{array}{l}\text { Biperiden } \\
\text { (mg/day) }\end{array}$ & 3 & $\ldots \ldots \ldots \ldots \ldots \ldots \ldots$ & $\begin{array}{lll}\ldots \ldots \ldots \ldots & 3\end{array}$ & & & 3 & $\cdots \cdots$ \\
\hline \multicolumn{8}{|l|}{ (i. m.) } \\
\hline \multicolumn{8}{|l|}{$\begin{array}{l}\text { Haloperidol } \\
\text { (mg, twice a day) }\end{array}$} \\
\hline $\begin{array}{l}\text { Biperiden } \\
\text { (mg, twice a day) }\end{array}$ & & & & 5 & $\begin{array}{ll}\cdots & 5\end{array}$ & & \\
\hline
\end{tabular}


TABLE 2

Concentrations of haloperidol and biperiden in maternal plasma and breast milk and in neonatal plasma

\begin{tabular}{lcccc}
\hline \multirow{2}{*}{ Source } & sampling time & $\begin{array}{c}\text { Hours since last } \\
\text { administration }\end{array}$ & \multicolumn{2}{c}{ concentrations $(\mathrm{ng} / \mathrm{ml})$} \\
\cline { 5 - 6 } mother's plasma & at delivery & $\begin{array}{l}3.5 \text { hours after } \\
\text { injection }\end{array}$ & 10.2 & 4.4 \\
neonate's plasma & at birth & - & 4.6 & N.D.* \\
\hline breast milk & $\begin{array}{l}\text { 12 th. day after } \\
\text { birth. }\end{array}$ & $\begin{array}{l}\text { 3 hours after oral } \\
\text { administration }\end{array}$ & 1.7 & Bi* \\
\hline
\end{tabular}

* N.D. : not detectable

** detection impossible due to another peak

thods. Plasma concentrations of haloperidol and biperiden in the mother and neonate, and breast milk drug concentrations are shown in Table 2.

\section{Discussion}

The phenothiazines are capable of crossing the placenta and appear in the urine and tissue of the newborn infant following administration of the drug to the mother (Moya et al. 1962). Maternal and neonatal haloperidol and biperiden plasma concentrations were not previously measured at the time of delivery. Cressman et al. (1974) reported that the mean plasma level of haloperidol was approximately $1 \mathrm{ng} / \mathrm{ml}$, 4 hours after the administration of $2 \mathrm{mg}$ haloperidol. In the present study, the maternal plasma concentrations, 3.5 hours after $5 \mathrm{mg}$ haloperidol and $5 \mathrm{mg}$ biperiden intramuscularly, were $10.2 \mathrm{ng} / \mathrm{ml}$ and 4.4 $\mathrm{ng} / \mathrm{ml}$ repectively. The serum concentrations of haloperidol reached a steady-state after approximately 6 days and the steadystate concentrations may vary up to tenfold between individuals given the same dose. Steady-state serum levels of haloperidol ranged from $3 \mathrm{ng} / \mathrm{ml}$ to $20 \mathrm{ng} / \mathrm{ml}$ in a study of 11 patients who were given $6 \mathrm{mg} /$ day of haloperidol (Forsman et al. 1974). Our result, $10.2 \mathrm{ng} / \mathrm{ml}$, was in this range.

The secretion of haloperidol in breast milk has been described (Stewart et al. 1980). The levels of haloperidol in breast milk were $5 \mathrm{ng} / \mathrm{ml}$ after an average dose of $30 \mathrm{mg}$ per day and $2 \mathrm{ng} / \mathrm{ml}$ following a 12 mg dose. Our result was $1.7 \mathrm{ng} / \mathrm{ml}$ following a dose of $6 \mathrm{mg} /$ day. This is a very low concentration of haloperidol. Stewart et al. (1980) calculated that an infant could receive a maximum of $0.0075 \mathrm{mg} /$ day of haloperidol. The effect of these low concentrations of haloperidol on a neonate is unknown and the rate of metabolism in the neonate is also not known.

The neonatal plasma concentration of haloperidol was determined at birth. There was no previous report on this value. The concentration was $4.6 \mathrm{ng} / \mathrm{ml}$, a reasonably high level. The neonate should be followed carefully and it is safer not to provide maternal breast milk.

Reports of drug-induced extrapyramidal dysfunctions in infants have been published (Hill et al. 1962; Tamer et al. 1969). Dugas et al. (1978) showed that plasma concentrations of haloperidol of 6 to $8 \mathrm{ng} /$ $\mathrm{ml}$ always lead to sedation and psychomotor dysfunction in children. Our newborn patient did not have any abnormalities on the neurological examination, but his plasma level of haloperidol was $4.6 \mathrm{ng} / \mathrm{ml}$. This high concentration of haloperidol may 
cause side effects in a neonate, but fortunately, this baby did not have any side effects. Biperiden may have prevented the side effects. Forsman et al. (1977) reported that biperiden did not affect the plasma concentration of haloperidol but did prevent the haloperidol-induced extrapyramidal side effects. But they did not determine the concentration of biperiden that was necessary to prevent the haloperidol-induced side effects.

Animal reproduction studies have not been conducted with biperiden. It is not known whether biperiden can cause fetal damage when administered to a pregnant woman or whether it can affect reproductive capacity (Ananth, 1976). We attempted to determine the plasma concentrations of biperiden in the mother and the neonate, because there are no reports on the plasma concentrations of biperiden. We could not detect biperiden in our neonate. This means that biperiden may not readily cross the placenta. However an underdetectable level of biperiden may prevent the side effects of haloperidol. The concentration of biperiden in breast milk could not be measured, because another peak disturbed the biperiden peak. It is not established whether this drug is excreted in human milk. The metabolism and effects of biperiden in neonates are unknown. The safety and effectiveness in children have not been established. Further investigations are needed to determine the concentrations of biperiden in plasma, especially in neonates, and in breast milk.

\section{Conclusion}

1. The plasma concentrations of haloperidol and biperiden were determined in an atypical pregnant woman and her neonate at delivery.
2. Haloperidol and biperiden concentrations in the breast milk were also measured.

3. Haloperidol seems to be a safe drug to control pregnant psychotic women during the third trimester.

4. Biperiden may prevent extrapyramidal dysfunctions in the neonate.

5. There are no reports on the plasma concentrations of biperiden in maternal and neonatal plasma at the time of delivery and the concentration in the maternal breast milk.

\section{References}

Ananth, J. (1976). Side effects on Fetus and Infant of psychotropic drug use during pregnancy. Int. Pharmacopsychiat. 11, 246-260.

Cressman, W. A., Bianchine, J.R., Slotnick, V.B., Johnson, P.C. and Plostnieks, J. (1974). Plasma level Profile of haloperidol in man following intramuscular administration. Europ. J. Clin. Pharmacol. 7, 99-103.

Dugas, M., Bianchetti, G., Zarifian, E., Fabiani, N., Durand, G. and Morselli, P.L. (1978). Haloperidol plasma levels in children. XI congress of C.I.N.P., Vienna, July 9-14.

Forsman, A. and Öhman, R. (1974). On the pharmacokinetics of haloperidol. Nordisk Psykiatrisk Tidsskrift. 29, 441-448.

Forsman, A. and Öhman, R. (1977). Applied pharmacokinetics of haloperidol in man. Curr. Therap. Res. 21, 396-411.

Hill, R. H., Desmond, M.M. and Kay, J.L. (1962). Extrapyramidal dysfunction in an infant of a schizophrenic mother. J. Pediat. 69, 589-595.

Moya, F. and Thorndike, V. (1962). Passage of drugs across the placenta. Am. J. Ocst. and Ginec. 84, 1778.

Stewart, R.B., Karas, B. and Springer, P.K. (1980). Haloperidol excretion in human milk. Am. J. Psychiatry, 137, 849-850.

Tamer, A., Mckey, R., Arias, D., Worley, L. and FoGEL, B. J. (1969). Phenothiazine-induced extrapyramidal dysfunction in the neonate. J. Pediat. 75, 479-480. 